\title{
Soğuk Savaşın Simgesi Berlin Duvarı ve Sinemadaki Yansimaları
}

\author{
DOI: $10.26466 /$ opus.797448
}

*

\section{Cem Yildırım*}

Dr. Öğr. Üyesi, İstanbul Ayvansaray Üniversitesi, Güzel Sanatlar, Tasarım ve Mimarlık Fakültesi, İstanbul/ Türkiye

E-Posta: cemyildirim@ayvansaray.edu.tr

ORCID: $\underline{0000-0001-7767-8715}$

\section{Öz}

İkinci Dünya Savaşı'nın sona ermesinin ardından, dünya üzerinde ideolojik bir hakimiyet kurmayı hedefleyen iki süper güç olarak ortaya çıkan Amerika Birleşik Devletleri ve Sovyetler Birliği arasındaki Soğuk Savaşın en somut şekilde yaşandığı yer Almanya olmuştur. Berlin şehri, Doğu Almanya sınırları içerisinde kalmasına rağmen Batı bloğu ülkeleri ve Sovyetler arasında yapılan bir anlaşma gereği ikiye bölündü. Doğu Alman yönetimi, vatandaşlarının daha özgür ve refah bir yaşamın olduğu Batı Almanya'ya kaçışlarını önlemek amacıyla 13 Ağustos 1961'de Doğu Berlin'in etrafina Batı kısmına tüm geçişleri kapatan bir duvar örmeye başladı. 9 Kasım 1989' da yıkılana kadar, Berlin duvarını aşarak Batı Berlin'e kaçmaya çalışan yüzlerce insan yaşamını yitirmiştir. Toplumsal ve politik bir olgu olarak Berlin Duvarı ve bu duvarın temsil etmiş olduğu Almanya'nın bölünmüşlüğ̈̈, sinema anlatılarına da yansmıştır. Berlin Duvarı'nı öykülerinin merkezine alan çok sayıda sinema filmi çekilmiştir. Bu çalışmanın amacı, politik bir olgu olarak Berlin Duvarı'nın ve 1961 ve 1989 tarihleri arasındaki Soğuk Savaş döneminde Doğu ve Batı Berlin'de yaşanılanların bu filmlerde ne şekilde yansıtıldıklarını çerçeve çözümlemesi yöntemi kullanılarak ortaya koymaktır. Bu çalışma, 1961 ve 1989 yılları arasında Berlin Duvarı ve Almanya'nın bölünmüşlüğünü öykülerinin merkezine alan ve çekimleri Berlin'de gerçekleştirilmiş olan dört uzun metrajlı kurmaca sinema filmiyle sinırlandırılmıştır.

Anahtar Kelimeler: Berlin Duvarı, Soğuk Savaş, Stasi, Doğu Almanya, Politik Film 


\title{
Berlin Wall: The Symbol of the Cold War and Its Reflections in Cinema
}

\begin{abstract}
After the end of the Second World War, Germany was the most concrete place in the cold war between the United States and the Soviet Union, which emerged as two superpowers aimed at establishing an ideological domination on the earth. Although the city of Berlin remained within the borders of East Germany, it was divided into two by an agreement between the Western bloc countries and the Soviets. On August 13, 1961, the East Berlin administration began building a wall around East Berlin that closed all the passages of the West section where its citizens had a more free and prosperous life on August 13, 1961. Until it was demolished on November 9, 1989, hundreds of people lost their lives trying to escape to the West Berlin by crossing the Berlin wall. The Berlin Wall as a social and political phenomenon and the division of Germany represented by this wall are also reflected in film narratives. A large number of motion pictures were made, which put the Berlin Wall at the center of their stories. The aim of this study is to reveal how the Berlin Wall as a political phenomenon and what happened in East and West Berlin during the cold war period between 1961 and 1989 were reflected in these films by using frame analysis method. This work is limited to four feature-length feature films that took the Berlin Wall and the division of Germany between 1961 and 1989 at the center of their stories and were shot in Berlin.
\end{abstract}

Keywords: Berlin Wall, Cold War, Stasi, East Germany, Political Film. 


\section{Giriş}

Savaşlar, katliamlar, göçler, direnişler ve isyanlar gibi tarih boyunca gerçekleşen pek çok politik ve toplumsal olay sinema anlatılarına yansımıştır. Hem gerçek olaylar hem de bu olaylara gönderme yapan hikayeler beyaz perdeye aktarılmıştır. Sinema, içinde var olduğu toplumu yansıtabilen etkili bir kitle iletişim aracıdır (Akmeşe ve Arda, 2020, s.2110). 13 Ağustos 1961 günü, Berlin Şehrinin ortasında inşa edilmeye başlanan duvar, şehrin batı kısmını tamamen çevreleyerek şehri Doğu Almanya'dan soyutlamıştır. Yıkıldığı 1989 y1lına kadar pek çok dramın yaşanmasına neden olan Berlin Duvarı, ayrıca dünya tarihinde Amerika Birleşik Devletleri ve Sovyetler birliği arasında sürekli bir gerginliğin ve sınırlı çatışmanın yaşandığı Soğuk Savaşın önemli bir simgesi olmuştur. Berlin Duvarı, Soğuk Savaşın ilk yıllarında Doğu Almanya vatandaşlarının Batı Almanya'ya geçişlerini engellemek amacıyla, Alman Demokratik Cumhuriyeti (Doğu Almanya) tarafından 1961 yılında inşa edilmiştir. Duvar, Batı Berlin'i tamamen Doğu Berlin ve Doğu Almanya'nın dışında bırakıyordu. Bu bariyere, geniş beton duvarlara yerleştirilmiş olan nöbetçi kulübeleri de dahil edilmişti. Çok geniş bir alanı (daha sonraları "ölüm şeridi" olarak adlandırılan) çember içine alan Berlin Duvarı, ayrıca araçların geçemeyeceği çukurları, çivili yol tuzaklarını ve diğer engelleri de içeriyordu. Doğu Bloku, bu duvarın Doğu Almanya'da sosyalist bir devlet kurmak isteyen halkın iradesini kırmak amacında olan faşist unsurlara karşı bir koruma olarak inşa edildiğini iddia ediyordu. Ancak Berlin Duvarı, aslen İkinci Dünya Savaşı sonrası dönemde Doğu Almanya'da yaşayan insanların Batı Almanya'ya yoğun bir şekilde göç ve iltica etmesini önlemeye hizmet ediyordu. Berlin Duvarı, Alman Demokratik Cumhuriyeti tarafından resmi olarak "Anti Faşist Koruma Siperi" (Antifaschistischer Schutzwall) olarak adlandırılıyordu. (Mering ve Wyman, 2013, s.1) Bu adlandırma, duvar dışında kalan Batı Almanya'nı "Nazi unsurları" ihtiva ettiğini ima ediyordu. Batı Berlin Valiliği, Berlin Duvarı'nı "utanç duvarı" olarak tanımlıyordu. Bu tanımlama, duvarın hareket özgürlügünü kısıtlamasını kınayan Batı Berlin valisi Willy Brandt tarafından yapılmıştı. (Delacroix, 2016, s.73) Doğu ve Batı Almanya'yı bölen bu sınır, aynı zamanda Batı Avrupa ve Doğu Bloğunu da ayıran bir "demir perde" olarak sembolize edilmişti. 
Sinemada anlatılan öyküler hem biçimde hem de içerikte yapılan bilinçli tercihler aracılığıyla belirli bir ideolojik bakış açısından seyirciye yansıtılabilir. Dünya tarihinde yaşanan pek çok toplumsal ve politik olay gibi, "Soğuk Savaş" dönemi ve bu dönemde Berlin şehrinde yaşananlar üzerine de pek çok sinema filmi yapılmıştır. Bu çalışma, Berlin Duvarının örülmesiyle ortaya çıkan toplumsal ve ideolojik atmosferin etkili bir kitle iletişim aracı olan sinema anlatılarında ne şekilde yansıtılmış olduğu sorusuna yanıtlar bulmayı amaçlamaktadır. Çalışma, bu bağlamda Berlin Duvarı'nı ve onun o zamanki hayatın bir parçası olduğu 1961 ve 1989 yılları arasındaki Doğu ve Batı Berlin'i hikayelerine yansıtan ve çekimleri Berlin'de yapılmış dört uzun metrajlı kurmaca sinema filmi ile sınırlandırılmıştır. Bu filmler, yönetmenliğini Roland Suso Richter'in yaptığı 2001 yılı yapımı Tünel (Der Tunnel), yönetmenliğini Wim Wenders'in yaptığı 1987 yılı yapımı Berlin Üzerinde Gökyüzü (Der Himmel Über Berlin), yönetmenliğini Florian Henckel Donnersmarck'ın yaptığ 2006 yılı yapımı Başkalarının Hayatı (Das Leben der Anderen) ve yönetmenliğini Guy Hamilton'un yaptığı 1966 yılı yapımı Berlin'de Cenaze (Funeral in Berlin) isimli yapımlardır.

\section{İkinci Dünya Savaşı Sonrası Almanya ve Soğuk Savaş}

İkinci Dünya Savaşı kesin bir barış antlaşması ile sona ermedi. Bunun yerine, silahlı güçleri ile bir ulusu Nazilerden kurtaran ülkeler nihayetinde o ulusların politik karakterlerini ve jeopolitik konumlarını da biçimlendirmiş oldular. Böylece Batı Avrupa uluslararası arenada özgür, demokratik ve genel olarak Amerika Birleşik Devletleri ile müttefik olarak belirdi. Doğu Avrupa ülkeleri ise Moskova tarafından kabul edilen komünist rejimler tarafından yönetilmeye başlandı. Bu ülkelerin askeri ve dış politikaları ise Sovyet yönetimine bağımlıydı. Almanya'nın içinde bulunduğu durum ise özel bir durumdu. Berlin ise çok daha özel bir durumda yer alıyordu. İngiliz, Sovyet ve Amerikan Birlikleri, Nazileri Almanya'nın değişik bölgelerinde yenilgiye uğrattılar. 4-11 Şubat 1945' de gerçekleştirilen Yalta Konferansında, bu "üç büyük güç" Almanya'nın dört geçici işgal bölgesi olarak bölünmesine (Fransa dördüncü işgalci güç oluyordu) karar verdiler. Almanya'nın başkenti Berlin, Sovyet işgal bölgesinin 177 kilometre içerisinde kaliyordu. 17 Temmuz- 2 Ağustos 1945 tarihinde gerçekleştirilen Postdam Konferansında Berlin'in de benzer bir şekilde, dört işgal bölgesine bölünmesine karar verdiler. (Friedman, 2019, s.2) 
Batı Avrupa'nın toparlanması açısından hayati önem taşıması nedeniyle, en azından kendi bölgelerinde Alman ekonomisini yeniden canlandırmaları ve bunu Almanya'nın gelecekteki siyasi yapısı yeniden belirlenmeden yapmaları gerektiği görüşünü kabul eden batılı güçler 1948'de, aralarındaki ticaret engellerini ortadan kaldırmak amacıyla kendi bölgelerinde bir para birimi reformu yaptılar. Bu reform son derce güçlü bir etki yaratarak, artık bir ekonomik varlığa dönüşmeye başlayan Batı Almanya'da ekonomik toparlanma sürecini başlattı. Ancak Sovyetlerin kararı nedeniyle sadece batı işgali altındaki bölgelere verilen Marshal Yardımı'nın ardından, bu reform Almanya'yı ikiye böldü. Batılı güçlerin Alman sanayisinin yeniden kendi ayakları üstünde durabilmesi için uğraşmaları ekonomik açıdan elbette gerekliydi, ama o andan itibaren Doğu Almanya demir perdenin diğer tarafında kalacaktı. (Roberts, 2003, s. 417)

Batıdaki para birimi reformu Sovyetlerin rızası alınmadan gerçekleştirilmişti ve Sovyetler Birliği tepkisini zaman kaybetmeden gösterdi. Berlin de, Sovyet işgal bölgesi içinde yalıtılmış durumda olmakla birlikte, para birimi reformuyla ikiye bölünmüş oldu. Sovyetler kentin batı işgal bölgeleriyle iletişimine halihazırda müdahale etmişlerdi ve kimi batılı yetkililer daha o zamandan, Batı Berlin' in tamamen tecrit edilebileceğini düşünmekteydiler. Haziran sonunda, Sovyet yetkililerin Berlin'le kara ve demiryolu bağlantılarını kesmesi "abluka" olarak yorumlandı. Sovyetler, Berlin halkına, batılı güçlerin artık kentin ihtiyaçlarını karşılamaya devam edemeyeceklerini göstermeyi hedefliyorlardı. Amerika ve İngiltere, Batı Berlin'in ihtiyaçlarını karşılamak amacıyla, şehre hava köprüsü kurdular. Böylece güç sınavı başlamıştı. Batılı güçler, Batı Berlin'in ayakta kalması için gerekli yiyecek, içecek, yakıt ve ilaç akışını bu şekilde sağlamanın yarattığı olağanüstü maliyete karşın, bunu sürdürmeye kararlı olduklarını belirttiler. Bu, sadece güç kullanılarak durdurulabilecekleri anlamına geliyordu. Savaştan beri, İngiltere'deki üslere ilk kez yeniden Amerikan stratejik bombardıman uçakları indi. Berlin'in havaalanlarına ve deniz uçaklarının inebileceği bir göle, günde binden fazla İngiliz ve Amerikan uçağı konuyor ve günde ortalama 5,000 ton kömür getiriliyordu. Müttefik ikmali kesilmediği için, Batı Berlinliler yıldırılamamışt. Bu, Batılı güçler için çok önemli bir siyasal zaferdi. Psikolojik açıdan, fetheden olmaktan çıkıp, koruyucuya dönüşmüşlerdi. 1949 yılının mayıs ayında Amerika, İngiltere ve Fransa'nın işgal ettiği bölgelerde yeni bir “Alman Federal Cumhuriyeti" kurulmuştu. Aynı yılın Ekim ayında da, doğuda resmi olarak 
Sosyalist Birlik Partisinin kontrolünde olan "Alman Demokratik Cumhuriyeti" kuruldu. Bundan böyle, artık iki Almanya vardı ve ikisini bölen demir perde boyunca artık bir soğuk savaş sürecekti. (Roberts, 2003, s. 418)

\section{“Gül Operasyonu": Bir "İç Sınır" olarak Berlin Duvarının İnşası}

1945 ve 1961 yılları arasında iki buçuk milyona yakın insan, politik özgürlük ve daha iyi yaşam şartları nedeniyle Doğu Almanya'dan Batı Almanya'ya kaçtı. Bu durum Alman Demokratik Cumhuriyeti'nin nüfusunun yaklaşık olarak yüzde on beş kadar azalmasına yol açtı. Göç edenlerin önemli bir kısmı genç ve yetişmiş insan gücünden oluşuyordu. Doğu Almanya, ihtiyacı olan eğitimli profesyonellerini ve kalifiye işçilerini kaybediyordu. 1961 yılının yazında bu toplu göç çok kritik seviyelere ulaşmıştı. Binlerce Doğu Almanyalı, her gün Batı Berlin'e kaçıyor ve buradan bir nevi "hava koridorları" olarak adlandırılan uçaklarla Batı Almanya'ya geçiyorlardı. (Taylor, 2006, s.vi.) 13 Ağustos 1961 de, Sosyalist Birlik Partisi, Batı Berlin' in tüm sınırına dikenli teller yerleştirmeye başladı. Duvarlar ise birkaç gün içerisinde yükselmeye başladı. Bu duvarla, Batı Berlin'e giderek büyüyen kitle göçünün engellenmesi umuluyordu. Sosyalist Birlik Partisi, bu duvarla aynı zamanda hem Doğu Alman halkına hem de dünyaya karşı gücünü ve iktidarını göstermek istiyordu. Ancak dikenli teller ve duvar, Doğu Berlin'den kaçışları tamamen engellemek için yeterli değildi. ("Construction", 2019)

Duvarın inşasının başlamasından iki ay önce, Alman Demokratik Cumhuriyeti Devlet Konseyi Başkanı Walter Ulbricht, "Niemand hat die Absicht, eine Mauer zu errichten!" (Hiç kimsenin sinıra bir duvar örmeye niyeti olmadığı) şeklinde bir beyanat vermişti. Daha sonraları günlük konuşma dilinde sıkça kullanılacak olan "Mauer" (Duvar) kelimesi, böylece ilk kez resmi bir ağızdan çıkmış oldu. (Taylor, 2006, s.137) Doğu ve Batı Almanya sınırı hali hazırda tamamen kapalı olmasına rağmen, bir kaçış ve yasa dışı para akış noktası olan Batı Berlin, Doğu Almanya ekonomisine büyük bir zarar veriyordu. 13 Ağustos 1961 de, Berlin halkı sabah erken saatlerde kamyon, traktör, vinç, askeri araçlar ve askeri marş sesleriyle uyand1. "Gül Dikeni” kod adı verilen bu operasyon çok gizli ve detaylı bir biçimde planlanmışt ve Batı Berlin sınırını tamamen kuşatan yaklaşık 20 bin Doğu Alman askerinin bile, sınır bölgesine ulaşana kadar sınıra bir duvar inşa edileceğinden haberi yoktu. (Kastner, 2002, s.113) Duvarın inşasıyla birlikte Doğu ve Batı Berlin arasında 
toplam 197 cadde tamamen kapandı. Ayrıca Batı Berlin'e geçen metro ve tren yolları kesintiye uğradı. Şehrin etrafında duvarlar yükselirken, Doğu Alman Radyosu herhangi bir resmi duyuru yapmayıp sadece müzik yayınlıyordu. İlerleyen günlerde çok daha fazla Doğu Alman birlikleri sinıra sevk edildi. Doğu Almanya hükümeti, “Anti-Faşist Korunma Bariyeri” olarak adlandırdığg Berlin Duvarı'nın, sosyalist devleti korumak amacıyla inşa edildiğini bildirdi. (Rottman, 2008, s.31)

\section{Ölüm Şeridi}

Doğu Berlinlilerin ve Doğu Almanya vatandaşlarının batıya kaçmalarını engellemek için inşa edilen bu duvara rağmen, kitlesel kaçışlar tam anlamıyla önlenemiyordu. Bunun sonucu olarak Doğu Almanya hükümeti, kaçsşları zorlaştırmak ve hatta imkansızlaştırmak amacıyla duvara sürekli yeni istihkamlar uygulayarak, çok katmanlı bir bariyer sistemi oluşturdu. Bu duvar, pek çok insanın kaçmaya çalışırken hayatını kaybetmesi üzerine, Berlinliler tarafından "ölüm şeridi" olarak anılmaya başlandı. Doğu Almanya yönetimi, Doğu Alman askerleri ve sınır polislerini pek çok engele rağmen batıya kaçmaya çalışan insanlara karşı silahlarla müdahale etmek zorunda bırakıyordu. Bu da Doğu Almanya sınırında pek çok insanın yaşamını yitirmesine yol açtı. 1961 ve 1989 yılları arasında sadece Berlin'de, çoğunluğunu batıya kaçmaya çalışan insanların oluşturduğu 90 kişi Doğu Alman sınır polisi ve askerleri tarafından vurularak öldürüldü. Bu yıllar arasında Berlin duvarıyla bağlantılı olarak çeşitli nedenlerden ötürü toplamda en az 137 insan yaşamını yitirdi. Duvarı ve sınır engellerini aşmaya çalışan 99 kişi vurularak, kaza geçirerek ya da intihar ederek öldü. Batı ve Doğu tarafından 30 kişi, kaçmaya yeltenmemelerine rağmen kaza ile vurularak öldürüldü. Görevi başındaki 8 Doğu Alman sınır askeri, kaçmaya çalışanlar ile kaçanlara yardım edenler ya da Batı Berlin polisi tarafından ya kazayla ya da kasten öldürüldüler. En az 251 kişi ise Berlin sınırındaki kontrol noktalarında sınırı geçerken ya da geçtikten hemen sonra yaşamlarını yitirdi. ("Fatalities", 2019) Bu ölümlerin kuşkusuz en dramatik olanlarından biri de 18 yaşındaki Peter Fechter'in hikayesidir. Peter Fechter, 17 Ağustos 1962' de bir iş arkadaşı ile birlikte, duvarı aşarak Batı Berlin'e kaçmaya çalışırken bir Doğu Alman sınır nöbetçisi tarafından kalçasından vurularak sınırı oluşturan duvarlar arasına düştü. Ne Doğu Alman sınır görevlilerinin ne de Batı Berlin tarafındaki müttefik askerlerinin iki 
sinır arasına girip yaralıya müdahale etme yetkisi yoktu. Peter Fechter, yaklaşık bir saat boyunca müdahale edilmeden orada kaldı ve bütün dünyanın gözleri önünde kan kaybından yaşamını yitirdi. ("Memorial”, 2019)

\section{Duvarın Yıkılışı ve Doğu Almanya Devleti'nin Çöküşü}

1975 yılında Helsinki' de yapılan ve Amerika Birleşik Devletleri'nin de dahil olduğu otuz beş ülkenin katılımıyla gerçekleştirilen "Avrupa' da güvenlik ve iş birliği" konferansında, Doğu Almanya liderleri -her ne kadar isteksizce de olsa- "insanların seyahat özgürlüğü hakları olması" konusunda görüş birliğine vardılar. Bunun hemen sonrasında giderek artan sayıda Doğu Alman vatandaşı, Batı Almanya' ya kalıcı olarak yerleşmek için başvuruda bulundu. Bununla birlikte Doğu Almanya'da var olan sosyal ve politik koşulları eleştiren bir muhalefet hareketi de giderek yükselmeye başladı. Buna benzer gelişmeler, Polonya örneğinde olduğu gibi diğer Doğu Bloku ülkelerinde de gerçekleşiyordu. ("The Fall”, 2019) 1985 yılında, Sovyetler Birliği'nde Mihail Gorbaçov'un Komünist Parti Genel sekreteri olmasından sonra Doğu Bloku yavaş yavaş değişmeye başladı. Gorbaçov ilk olarak bir takım politik reformlarla ekonomik ve sosyal problemleri çözmek için uğraş verdi. Gorbaçov, 1988 yılında Varşova Paktı'na bağlı olan ülkelerin iç ve dış politikalarına Sovyet müdahalesini sağlayan Brejnev Doktrininden vazgeçti. Bu değişim, Doğu Bloku ülkelerinin artık kendi ulusal politikaların belirleyebilmelerinin yolunu açtı. 2 Mayıs 1989'da, Macaristan kendi sınır tellerini bir gösteriyle yıkarak batıya geçişini sembolik olarak açıkladı ve böylece demir perdede ilk delik açılmış oldu. (Major, 2010, s.239) Doğu Almanya'nun Sosyalist Birlik Partisi ise ilk başlarda bütün bu gelişmelere ilgisiz kalmaya çalışt. Ancak seksenli yılların sonuna doğru Doğu Alman Halkı arasında giderek artan ve genişleyen protestolarla birlikte çok sayıda insanın Batı Almanya' ya göç etmesi Doğu Alman hükümetinin kaçınılmaz sonunu getiriyordu. Sosyalist Birlik Partisi, vatandaşlarının sınır ötesine geçmelerine izin verilmesi gibi konularda ödün vermekte çok zorlandı. 9 Kasım 1989'da sahte bir yeni göçmenlik yasası anons edildiğinde, binlerce insan sınıra doğru akın edip Berlin Duvarı'nı yıkmaya başladı. Berlin Duvarı'nın yıkılması, Doğu Almanya Devleti'nin de nihai çöküşünü getirdi. (Major, 2010, s.257) 


\section{Yöntem}

İnsanlık tarihi kesintisiz bir şekilde devam eden egemenlik kurma mücadeleleri ile doludur. Dünya tarihinde egemenlik kurma istenci ekseninde birçok mücadele pratiği mevcuttur (Akmeşe,2020, s.57). Berlin duvarı ve tarihsel süreç içerisinde ortaya çıan Soğuk Savaş süreci insanlık tarihinde yaşanan egemenlik kurma çabasının somut bir örneği olarak yerini almıştır. Çalışma kapsamında öncelikle Berlin Duvarı ve Soğuk Savaş döneminde yaşanan toplumsal ve politik olayların tarihsel arka planı ele alınmakta ve ardından örneklem olarak seçilen sinema filmleri "çerçeveleme çözümlemesi" yöntemiyle analiz edilmektedir. Çerçeveleme bir amaç doğrusunda yapılmaktadır. Çerçevelemede, çerçevenin içerisine dahil edilen kısım çerçeveyi kuran kişinin/yönetmenin ilgi merkezi olarak belirlediği ve görmemizi istediği noktadir. Kurulan çerçeve ile konu yeni bir bağlam içerisine yerleştirilir ve var olan gerçeklik yeniden biçimlendirilir. Yeniden inşa edilerek sunulan olay veya konu üzerinde çerçevelerin anlam oluşturan araçlara dönüştüğünü ifade etmek mümkündür. (Akmeşe, 2020, s.39-40) Betimlenen gerçekliğin özü, çerçevenin içerisine ne kadar dahil edildiği, neyin dışarıda bırakıldığı olayın biçimlendirilmesi ve hedef kitleye aktarılması açısından büyük önem taşımaktadır. (Entman, 1991, s.9) Çalışma, çerçeveleme çözümlemesi yöntemini kullanarak Berlin Duvarı ve tarihsel sürecin konu alındığı sinema filmlerini odağına alıp, dönemin yönetmenler tarafından nasıl çerçevelendiğini, hangi çerçevelerin kullandığını ve bu tarihi olaya tanıklık ederken betimlenen gerçekliğin nasıl yansıtıldığını tespit etmeye çalışmaktadır. Bu bağlamda örnekleme dahil edilen filmlerde "Berlin Duvarı" ve o dönemde yaşanılanların nasıl çerçevelendiği, yönetmenlerin dönemi hangi bakış açısıyla yansıttıkları ortaya konulmaya çalışılmıştır.

\section{Örneklem}

Çalışmamızda, 1961 ve 1989 yılları arasında, bir duvar ile bölünmüş olan Doğu ve Batı Berlin'i öykü evreninin temel ekseni olarak ele alan ve çekimleri Berlin'de gerçekleştirilmiş dört uzun metrajlı kurmaca sinema filminin çerçeve çözümlemesi yapılarak Berlin Duvarı ve o dönemde yaşananların film anlatılarında ne şekilde yansıttıkları ortaya konulmaktadır. Bu filmler, Tünel (Der Tunnel), Berlin Üzerinde Gökyüzü (Der Himmel Über Berlin), Başkalarının 
Hayatı (Das Leben der Anderen) ve Berlin'de Cenaze (Funeral in Berlin) isimli yapimlardir.

\section{Tünel (Der Tunnel)}

1961 yılının Ağustos ayında, Berlin'de Doğu Almanya sınırının kapanışı ve Berlin Duvarının inşasının başlamasıyla birlikte gelişen olayları ve yaşananları anlatan Tünel (2001), Almanya yapımı bir sinema filmidir. Esasen Alman televizyonlarında yayınlanacak bir televizyon filmi olarak çekilen Tünel, yirmi dakika kısaltılarak sinema salonlarında gösterime girdi. Berlin Duvarının var olduğu 28 yıl boyunca, Doğu Berlin'den Batı Berlin'e kaçmak için çok sayıda yer altı tüneli yapıldı ya da planlandı. (Kern, 2005) Yönetmenliğini Roland Suso Richter'in yaptığı ve gerçek olaylara dayanan Tünel, bu tünellerden ilkinin ve en ünlüsünün yapılış hikayesini anlatır. Filmin ana karakteri Harry Melchior, Doğu Almanya yüzme şampiyonudur. Harry, 1953 yılındaki gösterilere katıldığı gerekçesiyle tutuklanmış ve dört yıl hapis yatmıştır.

Melchior, 1961'deki ulusal yüzme şampiyonasına katılır ve kazanır. Daha sonra sahte bir pasaportla ve kılık değiştirerek Batı Berlin'e geçmeyi başarır. Ancak kız kardeşi ise eşi ve çocuklarıyla birlikte Doğu Berlin'dedir. Daha önceden Batı Berlin'e kaçmış olan Harry'nin en iyi dostu Matthis'in hamile eşi de Doğu Berlin'de kalmıştır. Yakınlarını ve sevdiklerini sıkı bir şekilde korunan Doğu Almanya sınırdan çıkarmak isteyen Harry ve bir mühendis olan Matthis, Berlin Duvarı'nın altından tünel kazarak amaçlarına ulaşmayı planlarlar. Başta Vittorio Constanza olmak üzere, diğer insanlarla da bağlantı kurarak planlarını gerçekleştirmeye koyulurlar. Öncelikle Berlin Duvarı'na yakın bir bölgede, boş ve geniş bir zemin katı olan bir fabrika bulup oradan tünel kazmaya başlarlar. Doğu tarafında kalan Nişanlısı Heiner'ı Batı Berline geçirtmek için uğraşan Fritzi Scholz isimli genç kız da onlara katılır. Ancak bu kişiler, zaman zaman tehlikeli olan ve çok yavaş ilerleyen tünel kazma işi için yeterli sayıyı oluşturamazlar. Bu nedenle, giderek çok daha fazla sayıda yakınlarını ve sevdiklerini Batı Berlin'e geçirmek isteyen insanların ekibe dahil olmalarını gönülsüzce de olsa kabul ederler. Bununla birlikte NBC televizyon ekibiyle, tünelin finansmanını sağlamaları koşuluyla tünelin ve planlanan kaçışın belgeselini çekmeleri konusunda anlaşırlar. 


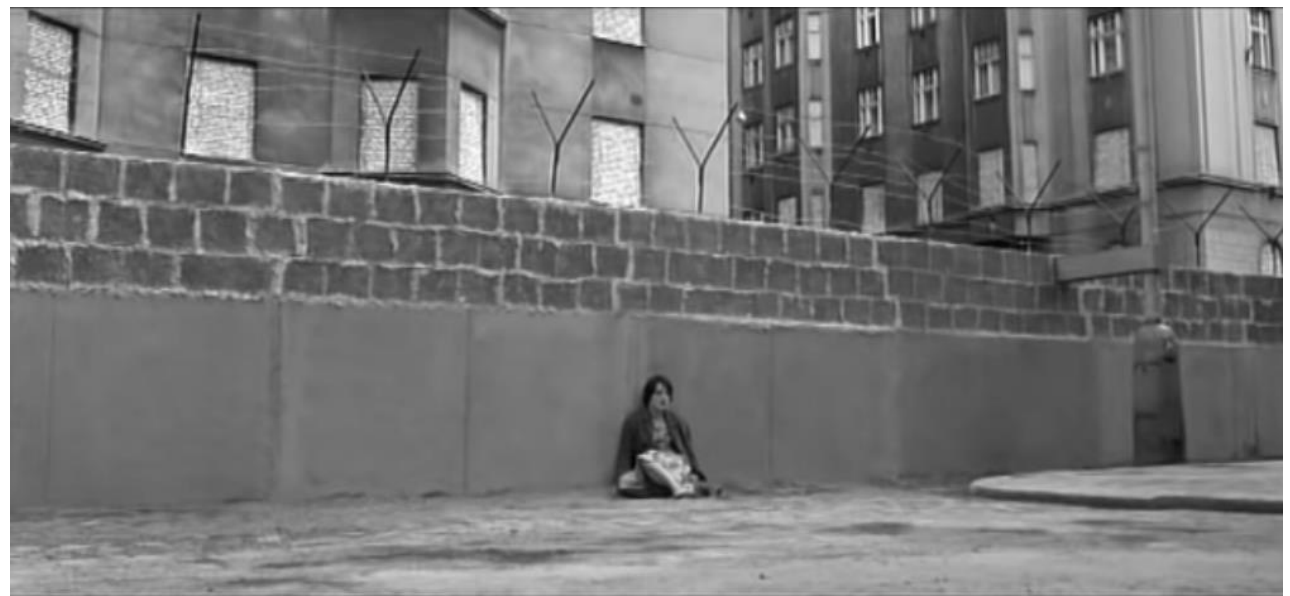

Şekil 1. Tünel Filminde Berlin Duvarn (Kaynak: Nico Hofmann (Yapımc) ve Roland Suso Richter (Yönetmen). (2001) Der Tunnel [ Sinema Filmi]. Almanya: Sat.1 teamWorx Television E Film.)

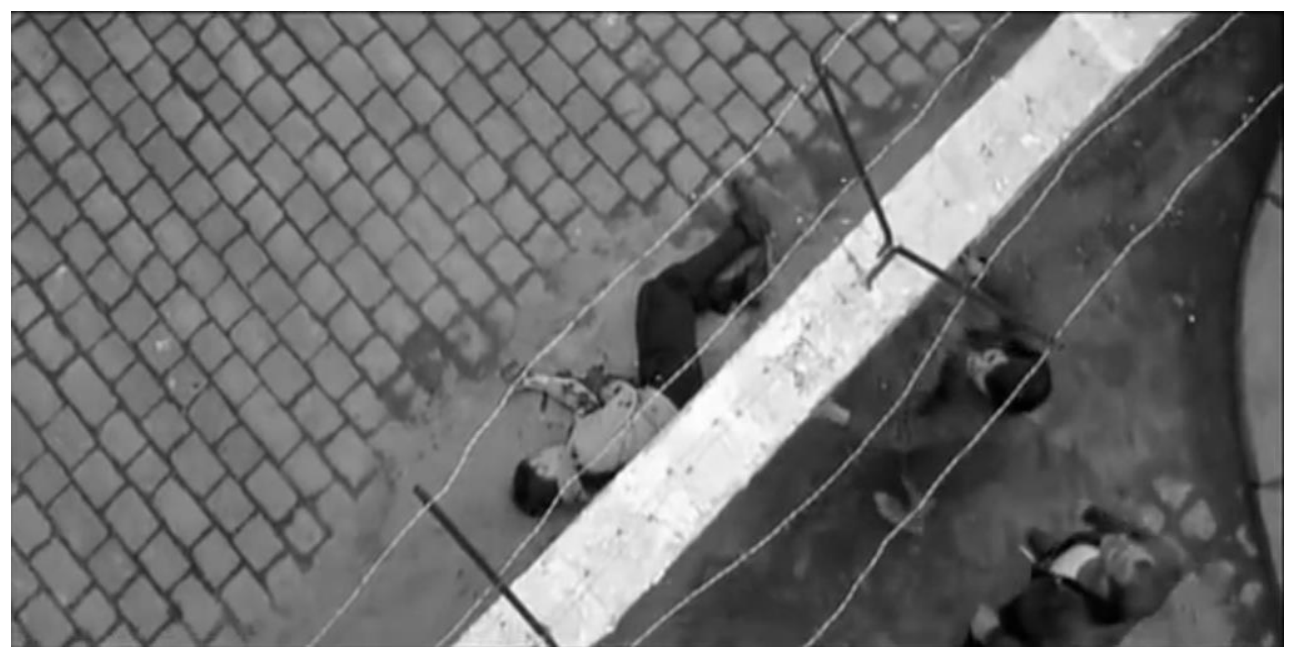

Şekil 2: Tünel Filminde Peter Fechter Temsili (Kaynak: Nico Hofmann (Yaptmcı) ve Roland Suso Richter (Yönetmen). (2001) Der Tunnel [ Sinema Filmi]. Almanya: Sat.1 teamWorx Television \& Film.)

Bununla birlikte, Batı tarafına geçirilecek insanlarla da iletişim halinde olmak gerekmektedir. Bu görevi de bir Amerikan vatandaşı olan ve özgür bir 
şekilde sınırdan geçebilen Vittoria üstlenir. Vittoria, Batıya kaçırılacak insanların yakınları ile kontak kurar. Ancak Doğu Alman gizli polis teşkilatı "Stasi", Harry'nin kız kardeşi ve Matthis'ın hamile eşi Carola'yı sürekli takip etmekte ve toplu bir kaçma eyleminin gerçekleşeceğinden şüphelenmektedir. Stasi çalışanı Albay Kröger, Carola'yı olası bir kaçış eylemi durumunda kendilerine bilgi vermesi için zorlamakta, aksi halde doğacak bebeğine Doğu Alman Devleti tarafından el konulacağı yönünde tehdit etmektedir. Bu arada tünel yapımı hızla ilerlemekte ve kaçış için tüm hazırlıklar tamamlanmak üzeredir. Tünel, insanların yakınlarını ve sevdiklerini Doğu Berlin'den Batı Berlin'e kaçırmak için yapılan ilk tünelin hikayesini anlatır. Filmin karakterleri endüstriyel bir yardım ya da bir devlet sponsorluğu olmadan, gerçekleştirilmesi nerdeyse olanaksız bir görevi başarmak için tutkulu bir şekilde mücadele ederler. Filmin bir sahnesinde Fritzi'nin nişanlısı Heiner, umutsuz bir şekilde dikenli telleri ve Duvarı aşarak Batı Berlin'e kaçmaya çalışırken sınır polisi tarafından vurulur ve iki sınır arasında ölüme terkedilir. Bu sahne (Şekil 2.), Peter Fechter'in ölümüne gönderme yapmaktadır.

Tünel filmi, Berlin Duvarı'nı Sovyet kontrolündeki Doğu Almanya'nın baskıcı rejiminin korkunç bir simgesi olarak yansıtmakta ve karakterlerin bu dayanılmaz yaşamdan kaçabilmek uğruna hayatlarını kaybetmeyi göze aldıklarını ve hatta Şekil.2'deki sahnede de gösterildiği üzere öldüklerini vurgulamaktadır. Filmin anlatısında duvar, Doğu Alman rejiminin öne sürdüğü gibi halkını saldırılardan korumak için inşa ettiği bir "Anti-Faşist Korunma Bariyeri" değil, aksine kendi halkını içeride tutmak, batıya kaçmalarını önlemek için inşa edilmiş bir yapı olarak çerçevelenmiştir. Filmde o yıllarda Doğu Almanya' da gelişmekte olan polis devletinin de (Stasi) portresi çıkarılmaktadır. Tünel filminde, politik gerilimin anlatının sonuna kadar korunduğu bir yapı oluşturulmuştur. Bu yapı, her an gerçekleşebilecek bir yakalanma, ihanet tehdidi ya da tüneldeki su borusunun patlama ihtimali gibi unsurlar kullanılarak gerçekleştirilmiştir. Filmin hikayesinin dayandığı, daha sonradan Batı Berlin'e kaçmış olan o yılların gerçek yüzme şampiyonu Hasso Hershel, 1953 yılında Doğu Berlin'deki komünist devlet karşıtı protestolara katıldığ gerekçesiyle yıllarca hapiste yatmıştır. Hasso Hershel, filmin DVD'sinin ekstra bölümlerinde tünel kazma işinin zorluklarını ve buna rağmen o tüneli bitirmeleri gerektiğine olan inançlarını anlatır. Hershel, filmin tünel sahnelerine bakarak, filmdeki tünelin kendisinin hatırladığından daha küçük olduğunu söylemiştir. (Corliss, 2011) 


\section{Berlin Üzerinde Gökyüzü (Der Himmel Über Berlin)}

Yönetmenliğini Yeni Alman Sinemasının öncü yönetmenlerinden Wim Wenders'in yaptığı Berlin Üzerinde Gökyüzü, Berlin Duvarının yıkılmasının yaklaşık iki yıl öncesi olan 1987 yılında Berlin'de çekilmiştir. Film, gerçeküstü bir anlatıma ve şiirsel-gerçekçi bir yapıya sahiptir. Wim Wenders, filmin senaryosunu Avusturyalı yazar Peter Handke ile birlikte yazmıştır. Filmin şïrsel diyaloglarıyla birlikte, filmde ara ara tekrarlanan "Çocukluk Şarkısı" isimli şiir de Peter Handke' ye aittir.

Film, Berlin Duvarı'nın varlığını sürdürdüğü, savaşın yaralarının ise halen hissedildiği seksenli yılların bölünmüş Berlin şehrinde, zamanın başlangıcından beri orada olan ve tarih boyunca doğanın ve insanların geçirdiği bütün değişimlere tanık olan, insanlara görünmeyen Damiel ve Cassiel isimli iki meleğin öyküsünü anlatır. Her şeyi gören ama hiçbir şeye müdahale edemeyen bu iki melek, sürekli insanları gözlemleyip düşüncelerini okurlar. Film boyunca Soğuk Savaşın hala sürdüğü bu bölünmüş şehirde, insanların depresif ruh halleri bu iki melek aracılığı ile yansıtılır. Meleklerin tanıklık ettiği Berlinlilerin sıkıntıları, varoluşsal kaygıları ve parçalanmış hayatları aslında hiçte bundan farklı olmayan Berlin şehrini (Şekil 3.) fon olarak kullanılarak anlatılır. Ara sıra küçük işaretlerle varlıklarını çevrelerindekilere hissettirebilen bu melekler, insanlara ve olaylara karşı herhangi bir müdahalede bulunamazlar.

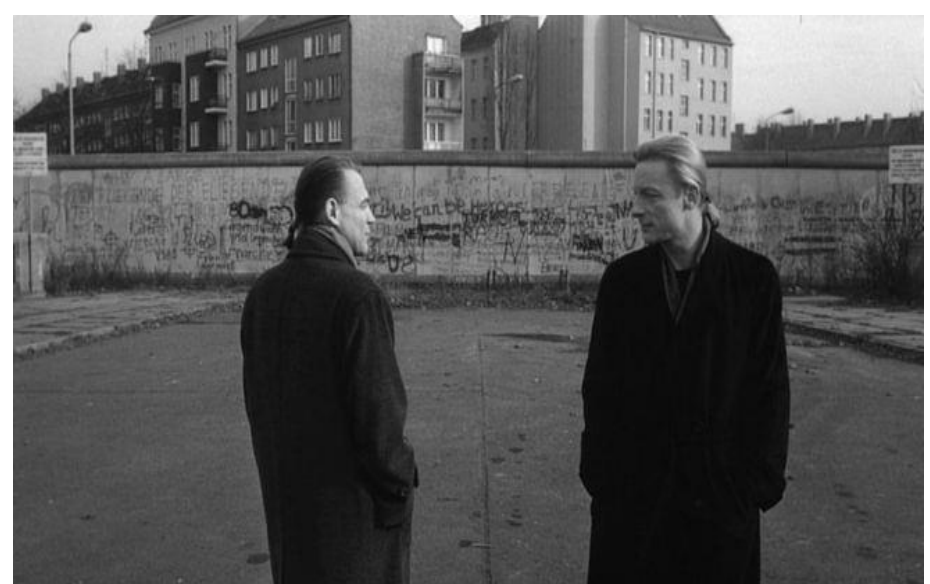

Şekil 3. Berlin Üzerindeki Gökyïzü Filminde Berlin Duvarn (Kaynak: Anatole Dauman (Yapımcı) ve Wim Wenders (Yönetmen). (1987). Der Himmel über Berlin [Sinema Filmi], Batı Almanya-Fransa: Road Movies Filmproduktion.) 
(Wenders ve Hofmann, 1991, s.79) Bu iki melekten Damiel, gerçek yaşamı giderek merak etmeye başlayarak ölümsüz olmaktan sıkılır ve ölümlülerin arasına karışmaya karar verir. Damiel, bir gün gittiği küçük bir Fransız sirkinde, Marion ismindeki trapezciye aşık olur. Damiel, bu sirkin ekonomik nedenlerle kapanmak üzere olduğunu öğrenince, artık ölümlü bir insan olup Marion'la yaşamaya karar verir. Filmde kendisini canlandıran oyuncu Peter Folk ise, daha önceden ölümsüz olmayı seçmiş bir melektir. Folk, Damien'e insan olma deneyiminin kahve ve sigara gibi basit keyiflerini açıklayarak Damien'in ölümsüzlüğe geçişine yardımcı olur. (“Wings of Desire”, 2019)

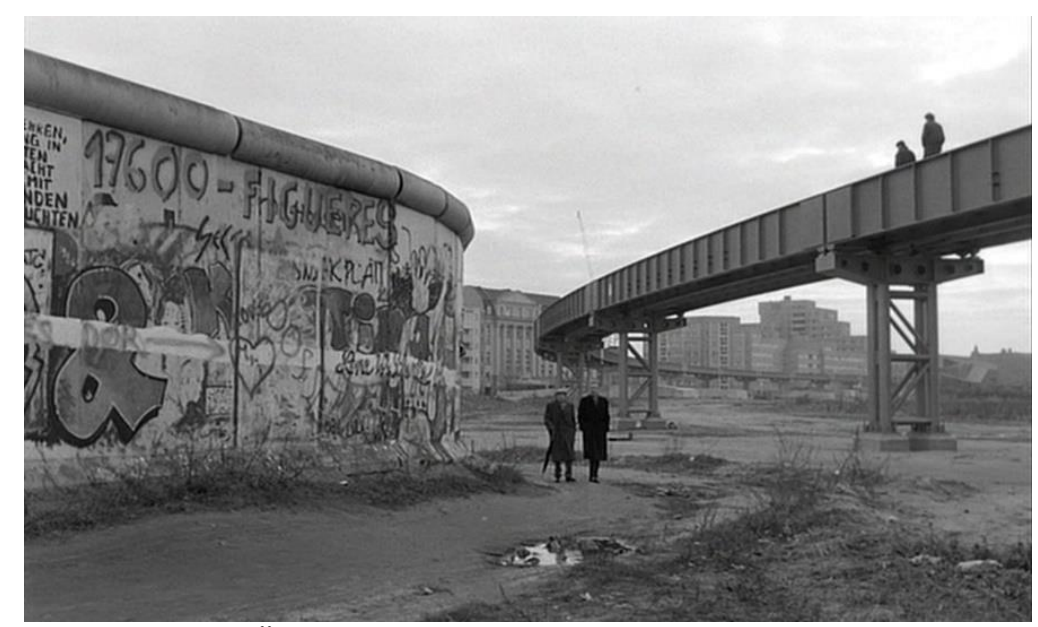

Şekil 4. Berlin Üzerindeki Gökyüzü Filminde Postdamer Platz Sahnesi (Kaynak: Anatole Dauman (Yaptmc) ve Wim Wenders (Yönetmen). (1987). Der Himmel über Berlin [Sinema Filmi], Batı Almanya-Fransa: Road Movies Filmproduktion.)

Berlin Üzerinde Gökyüzü, bölünmüş bir şehir olarak Berlin'in işlendiği en önemli filmlerden biridir. İzleyici, duvarın her iki yanında Berlin'de yaşayan pek çok insanın endişe ve korkularını öğrenmektedir. Bunların arasında, Damiel' in aşık olduğu ve uğruna ölümsüzlükten ve bu yaşamın kazandırdıklarından vazgeçtiği trapez sanatçısı Marion da bulunmaktadır. Doğu ve Batıyı, duvarı ve ölüm şeridini gösteren çekimler, duvarın yıkılmasından dolayı filmin çekimlerinden yaklaşık iki yıl sonra tarihsel bir önem kazanmıştır. Wim Wenders hakkında kitaplar yazmış olan yazar Reinhold Rauh film hakkında şunları yazmıştır: "Halen duvar ile bölünmüş Berlin'le ilgili belgesel bir filmdir. 
Görünüşe göre Wenders'in melekleri, insanlara olan inançlarım kaybetmemekte haklılarmıs." Bunu tarihsel bir belge olarak yorumlayan Graf ise, filmle ilgi olarak şunu belirtmiştir: "Film, tıpkı melekler olarak geçmişteki olaylardan, zaman içerisinde değişen ya da kaybolan nesnelerin bir kaydını tutarak onlarnn gelecek için tekrar ortaya çıkmalarmı sağlama gücüne sahiptir." (Munter, 2008, s.414-415.)

Filmin Berlin Duvarı ve soğuk savaşı vurgulayan en önemli sahnesi ise, İkinci dünya savaşında bombalanarak yok edilen ve o yıllarda duvarın geçtiği bölgede bulunan ve bomboş olan şehrin ünlü meydanlarından Postdamer Platz'a gelen yaşlı bir Yahudi adamın, eskiden bu meydanın nasıl kalabalık ve canlı bir yer olduğunu, o meydanda nasıl vakit geçirdiğini anlatıp, hüzünlü gözlerle o zamanki boş alana bakıp: "Burası Postdamer Platz olamaz" dediği sahnedir. (Şekil 4.) "Postdamer Platz" meydanı, Berlin Duvarının yıkılmasından sonra hızla gelişip, gökdelenlerin yükseldiği bir iş merkezi olmuştur. Aynı zamanda günümüzde Berlin Film Festivali gösterimlerinin yapıldığı ünlü sinemaların bulunduğu alandır. Filmin, meleklerin öznel bakış açısindan (point of view) anlatıldığı bölümleri siyah beyaz çekilmiştir. Meleklerin ölümsüzlüğü seçip, insan türünün gerçeklerini algılamaya başladığı bölümler ise renklidir. Filmin görüntüleri, 2001 yılında hayatını kaybeden efsanevi görüntü yönetmeni Henri Alekan tarafından çekilmiştir. Alekan, bu filmde, yerçekiminden bağımsız hissi veren uçarcasına görüntüler elde etmiştir. Wim Wenders, filmde geçen sirke bu usta görüntü yönetmenine bir jest olarak "Alekan Sirki" adını vermiştir. Orijinal Adı Der Himmel über Berlin olan film, Amerika Birleşik Devletleri'nde Wings of Desire adıyla gösterilmiş, ülkemizde ise Arzunun Kanatları adıyla piyasaya sürülmüştür. Filmin sonuna "devam edecek" ibaresi koyan yönetmen Wim Wenders, 1993 yılında bu filmin devamı niteliğinde olan Öylesine Uzak, Öylesine Yakm (In Weiter Ferne, So Nah) isimli filmi çekmiştir. Wim Wenders, ayrıca filmin sonuna, "Tüm eski meleklere, özellikle de Ozu, Francois, ve Andrzej'e ithaf edilmişdir" yazısın ekleyerek, yönetmenler Yasujira Ozu, Francois Truffaut ve Andrzej Wajda'ya saygı duruşunda bulunur. Bu filmin, 1998 Hollywood tarafından Melekler Şehri (City of Angels) adında yeniden çevrimi yapılmıştır. Bu yeniden çevrilen film ise Berlin yerine, Los Angeles şehrinde geçmektedir. 


\section{Berlin'de Cenaze (Funeral in Berlin)}

1966 yılı İngiliz yapımı olan Berlin'de Cenaze'nin senaryosunu, İngiliz yazar Len Deighton kendisine ait aynı adlı romanından uyarlamıştır. Oyuncu Michael Caine'nin canlandırdığı İngiliz İstihbarat Servisi M.I.5 ajanı "Harry Palmer" üçlemesinin ikincisi olan filmin yönetmeliği Guy Hamilton'a aittir. Filmin hikayesi 1960'lı yıllarda soğuk savaş hatlarının böldüğü Berlin'de geçer. Komünist Doğu Berlin'in insanları giderek artan bir şekilde Batıya kaçmaktadır. Berlin Duvarı'na rağmen kaçışlar yoğunlaşmakta ve genellikle başarıya ulaşmaktadır.

Sovyetler Birliği'nin Berlin Bölgesi istihbarat lideri ve aynı zamanda Berlin Duvarı üzerinden meydana gelen kaçışları önlemekle sorumlu olan Rus Albay Stok, Batı Berlin'deki batı müttefik ülkelerinden biri olan İngiltere'nin istihbarat birimleriyle iletişime geçerek kendisinin de Batı'ya kaçmak istediğini bildirir. Bunun üzerine oyuncu Michael Caine tarafından canlandırılan İngiliz istihbarat ajanı Harry Palmer, Albay Stok'un kaçma isteğinin gerçek olup olmadığını öğrenmek ve kaçışını organize etmek amacıyla, İngiliz istihbarat servisi tarafından Berlin'e gönderilir. Harry Palmer, İngiliz istihbaratı için çalışan Alman ajanı Johnny Vulkan'ın organize etmesiyle Doğu Berlin'e geçerek Albay Stok ile buluşur. Albay Stok, batıya kaçması karşılığında İngiliz hükümetinden maaş ve şehir dışından bir ev talep eder. Stok ayrıca kaçışının, sınırdan yapılan bütün başarılı kaçışları organize eden Kreutzmann adındaki Berlinli bir gangster tarafından organize edilmesini ister. Albay Stok, Kreutzmann'ın planladığı bu kaçışlar yüzünden kendi departmanının soruşturulmaya başladığını ve başının belaya girebileceğini ve bu yüzden bir an önce batıya kaçması gerektiğini de bildirir. 


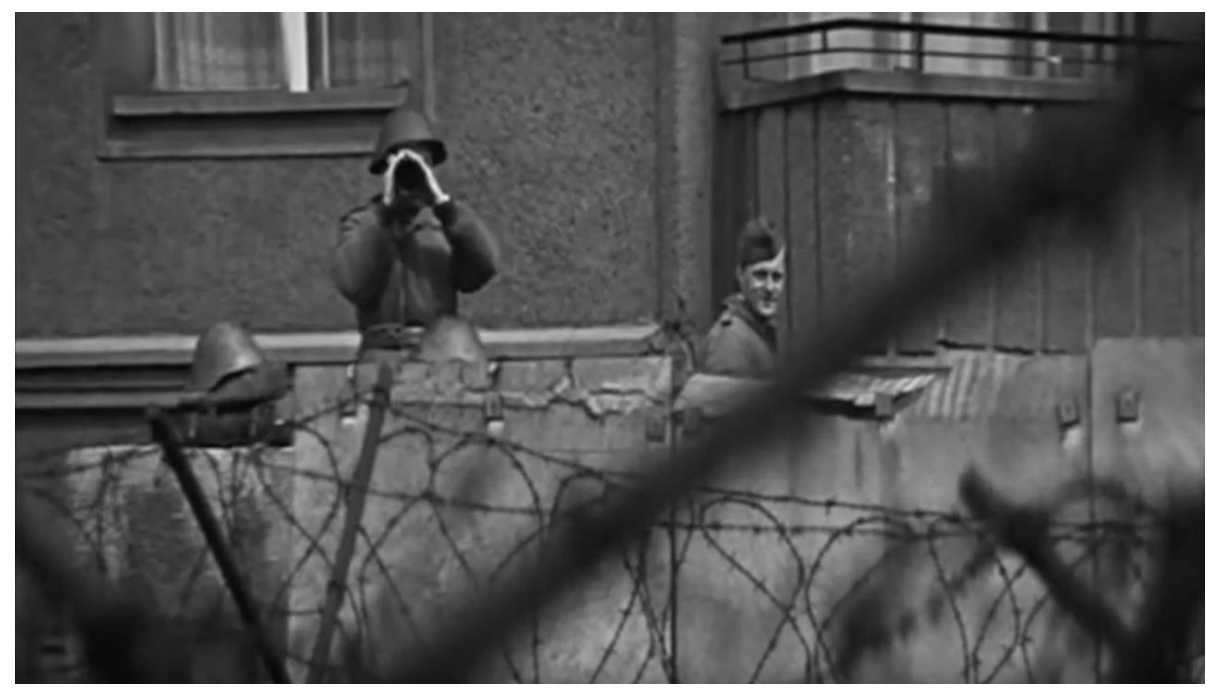

Şekil 5. Berlin'de Cenaze Filminde Berlin Duvarı (Kaynak: Charles D. Kasher (Yapımcı) ve Guy Hamilton (Yönetmen). (1966). Funeral in Berlin [Sinema Filmi]. Birleşik Krallik: Jovera Pictures AG/SA.)

Harry Palmer, Kreutzmann ile iletişime geçerek kimin kaçırılacağı bilgisini vermeden kaçış planını başlatır. Fakat olaylar film boyunca çok farklı bir şekilde gelişir. Filmin hikâye örgüsüne, farklı amaçlar için çift yönlü çalışan casuslar, İsrail ajanları ve Nazi savaş suçluları da girer ve böylelikle filmin kurgu yapısı izleyicinin takip etmesini zorlaştıran karmaşık yapıya bürünür. (Crowther, 1966) Berlin'de Cenaze filminin çeşitli sahnelerinde, Doğu Berlin s1nırından kaçışlar, Berlin Duvarı (Şekil 6.) ve kontrol noktası "Checkpoint Charlie" ye (Şekil 5) yer verilerek Berlin'in bölünmüşlüğü ve Soğuk Savaş ortamının gergin atmosferi etkili bir şekilde yansıtılmıştır.

Filmin açılış sahnesinde, Doğu Berlin sınırında mayın döşeme işinde çalıştırılmakta olan bir İşçi, Batı Berlin tarafında bulunan bir vinçe bağlı beton kovasının doğu sınırına uzatılmasıyla birlikte (Şekil 6.), koşarak beton kovasının içine atlar ve Batı Berlin'e kaçırılır. İşçinin beton kovasına doğru koşmaya başlamasıyla birlikte bir Doğu Alman subayı, işçinin ardından uzun namlulu silahla ateş etmeye başlar. 


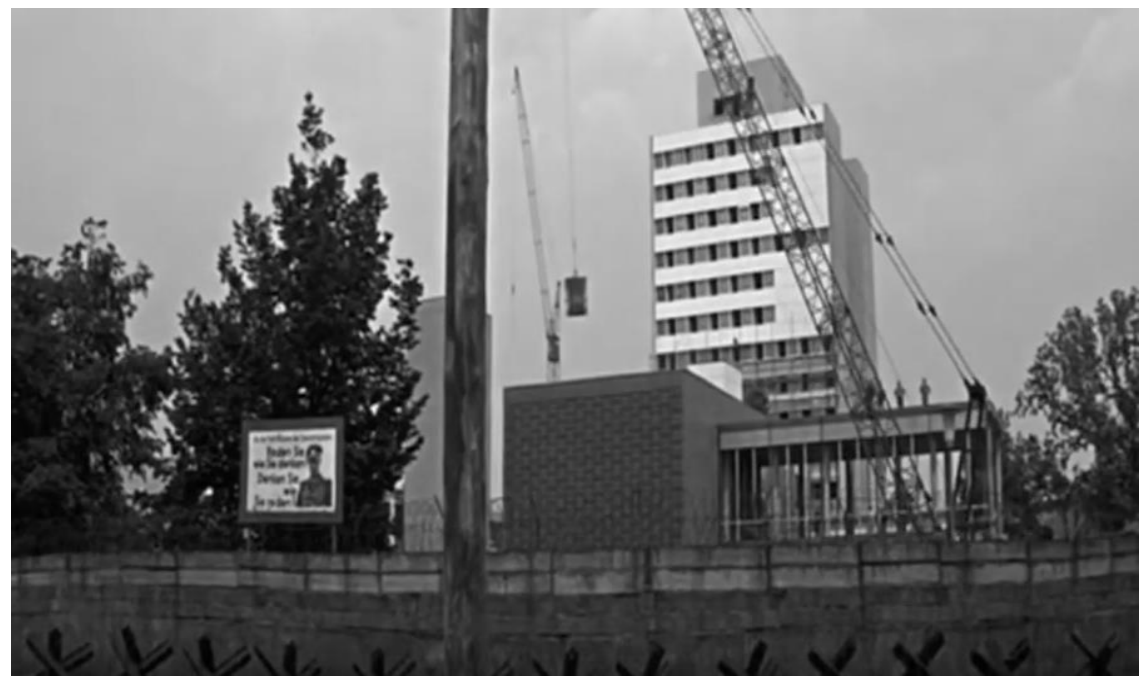

Şekil 6. Berlin'de Cenaze Filminde Doğu Berlin'den Kaçış (Kaynak: Charles D. Kasher (Yapımcl) ve Guy Hamilton (Yönetmen). (1966). Funeral in Berlin [Sinema Filmi]. Birleşik Krallik: Jovera Pictures AG/SA.)

Bütün bu kaçış sahneleri ve Şekil 5.'te de görüldüğüü üzere doğu sınırının ön planda duvar üzerindeki dikenli teller ile arka planda gözetleme yapan doğu Alman askerleriyle çerçevelenişi, Doğu Berlin'i içinde yaşamanın dayanılmaz olduğu korkunç bir hapishane olarak resmeder. İnsanlar, baskıcı, totaliter Sosyalist bir yönetimin hâkim olduğu klostrofobik bir yaşamdan kaçabilmek için ölümü bile göze alabilmektedir.

\section{Başkalarının Hayatı (Das Leben der Anderen)}

"Başkalarımın Hayatı", senaryosu ve yönetmenliği genç Alman yönetmen Florian Henckel Donnersmarck'a ait olan, 2006 yılında yapılmış bir Alman politik gerilim filmidir. Filmin hikayesi, 1984 yılında henüz Berlin Duvarının y1kılmadığı Doğu Almanya'da başlar ve Berlin Duvarının yıkılmasından iki yıl sonrasına, 1991 yılına kadar devam eder. Soğuk Savaşın son dönemlerini anlatan film, totaliter Doğu Almanya'da rejimi korumak amaciyla "Stasi" adıyla kurulan ve bünyesinde binlerce istihbarat görevlisi ve gizli polisin çalıştığ güçlü ve acımasız bir istihbarat ve güvenlik örgütünü hikayesinin temeline oturtur. Doğu Alman Cumhuriyeti'nin devlet güvenlik sistemi ile özdeş olan "Stasi", kamuyu etkileyen aydınlar, yazarlar ve sanatçılar başta olmak üzere 
"potansiyel tehdit olarak" algıladığı herkesi sürekli gözetliyordu. (Ramos, 2007) Yazar George Orwell'in "1984" isimli romanına gönderme yapan film şu jenerik yazısı ile başlar: "Yıl 1984. Doğu Berlin. Düşünce özgürlü̆g̈̈ çok uzak. Doğu Almanya Cumhuriyeti, Doğu Alman gizli polisi "Stasi" tarafindan sikı denetim altında tutulmakta. 100 bin çalışanı ve 200 bin muhbiri ile halk gözetim altına alınmakta. Açıklanan amaç "her şeyi bilmek!" (Cerrahoğlu, 2013)

Filmin ana karakteri, Alman oyuncu Ulrich Mühe tarafindan canlandırılan Stasi örgütü çalışanlarından biri olan ve aynı zamanda örgütün akademisinde eğitmen olarak da çalışan Yüzbaşı Gerd Wiesler'dir. Yüzbaşı Wiesler, bir akşam amiri ve aynı zamanda okul arkadaşı olan Yarbay Grubitz tarafından bir tiyatro oyunun galasına götürülür. Oyun sırasında dönemin Kültür Bakanı Bruno Hemph, Yüzbaşı Wiesler'ı oyunun yazarı Georg Dreyman'1 takip etmekle görevlendirir. Dönemin Doğu Almanya'sında başarılı bir yazar ve aslında sıkı bir komünist rejim destekçisi olan Dreyman, sözde rejim muhalifi olabileceği şüphesini taşımaktadır.

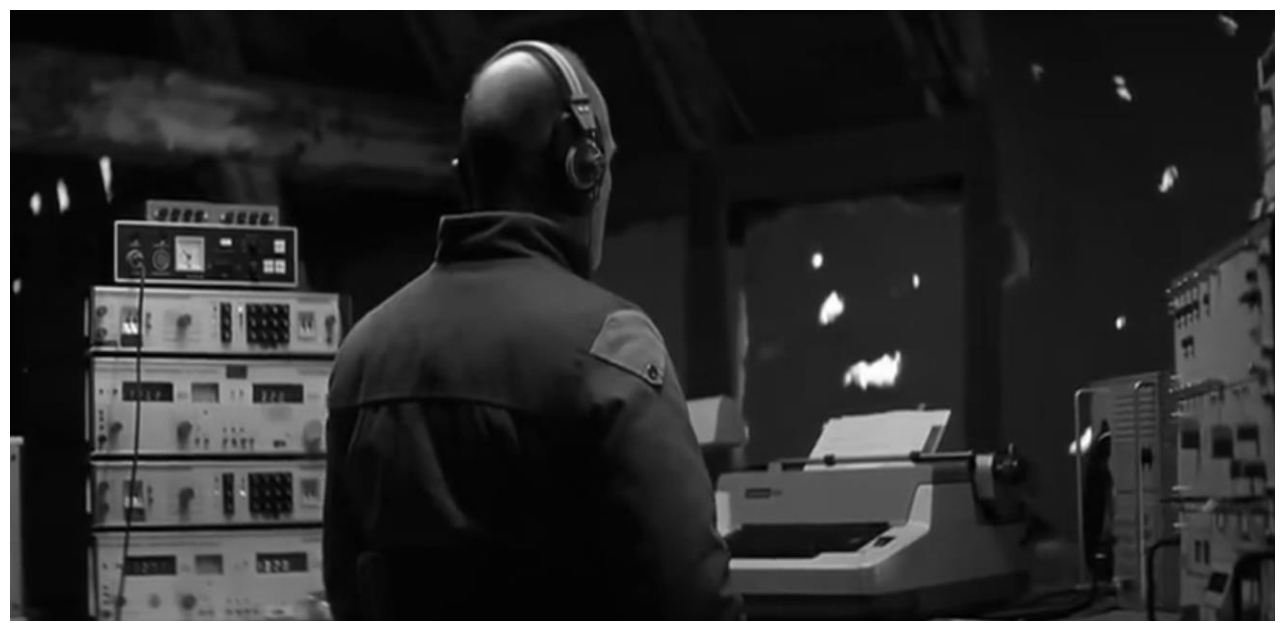

Şekil 7. Başkalarının Hayatı Filminde Stasi Operasyonu (Kaynak: Quirin Berg (Yapimci) ve Florian Henckel von Donnersmarck (Yönetmen). (2001). Das Leben der Anderen [Sinema Filmi], Almanya: Wiedemann \& Berg Filmproduktion.)

Ancak, Kültür Bakanı aslında yazar Dreyman'ın kız arkadaşı olan aktris Christa Maria Sieland'a ilgi duymaktadır. Dreyman'ı takip ettirmesindeki asıl amaç budur. 
Yüzbaşı Wiesler, ekibiyle birlikte yazar Dreyman'ın evine dinleme cihazları yerleştirerek, Dreyman ve kız arkadaşı Christa'yı sürekli takip eder. Yaptıkları her şeyi ve bütün konuşmalarını en özel ayrıntılarına varıncaya kadar kayda geçirir. Artık onların hayatlarının tümüyle içindedir. Dreyman, uyuşturucu ilaç alışkanlığı olan kız arkadaşı Christa'nın, Bakan Hemph tarafından bir süredir şantajla cinsel ilişkiye zorlandığı gerçeğini öğrenir. Bununla birlikte Dreyman'ın, rejim tarafından muhalif olduğu gerekçesiyle kara listeye alınan yönetmen bir arkadaşı, yıllardır işsiz olması nedeniyle intihar eder. Bütün bunlardan rahatsızlık duymaya başlayan Dreyman, Batı Almanya' da yayınlanan "Der Spiegel" dergisine Doğu Alman rejiminin sanatçılara karşı tutumu üzerine eleştirel bir yazı yazar. Bütün bunları bilen Yüzbaşı Wiesler, Dreyman ve Christa hakkındaki tüm sırları öğrenmesinin ardından onlara empati duymaya başlar. Bu nedenle onları ihbar etmez, aksine elindeki teknik imkanları kullanarak onları "Stasi" ye karşı korumaya çalışır. Yıllar sonra Berlin Duvarı yıkılıp Doğu ve Batı Almanya birleştiğinde, "Stasi" kayıtları halka açılır. Böylece, Dreyman o günlerde kendilerine yardım eden bu ajanın kim olduğunu öğrenecektir.

Yönetmen Florian Henckel Donnersmarck'in ilk uzun metrajlı sinema filmi olan Başkalarının Hayatı, eleştirmenler tarafından Doğu Alman diktatörlüğüne "ilk önemli ve ciddi sinemasal bakış" olarak değerlendirilmiştir. (Brockmann, 2010, s.490) Yönetmenin, Başkalarının Hayatı ile ilgili filmin resmi internet sitesinde yayınlanan görüşü ise şu şekildedir:

" Benim annem ve babam köken olarak Doğu Almanyahdır. Ben de çocukken pek çok kez, arkadaşlarımı ve akrabalarımı görmek için Doğu Almanya' ya giderdim. Babamın kuzenlerinden biri Sosyalist Birlik Partisini ve Doğu Alman Devletinin başkam olan Erich Honocker' in protokol şefiydi. Tanıdığımız diğer insanların ise normal mesleklerivard. Rejimin en tepesinden, en altına kadar insanlarm yüzlerindeki korkuyu görebiliyordunuz.: Stasi'nin korkusu, 100 bin eğitimli Stasi çalışanın korkusu. Stasi çalışanları tek bir şey için eğitilmişlerdi: "Başkalarmnn Hayatı", "Farklı dü̧̧ünenlerin hayatı, Özgürce düşünme güdüsü olan herkes, sanatçlar ve sanat için çal-şan insanlar. Yaşamın her yönü kaydediliyordu. Özel ve kutsal olan hiçbir şey yoktu. Hapislerde yatmış ve sorgulanmış Stasi kurbanlar ile konuştum. Filmde her karakter bizim sürekli yüzleştiğimiz şu soruyu soruyor: Güç ve İdeoloji karşısında ne yapıyoruz: Prensiplerimize mi yoksa duygularmiza mi göre hareket ediyoruz?"("The Life", 2019) 
Filmde, totaliter ve korku verici Doğu Almanya özellikle Kültür Bakanı Bruno Hemph ve Yarbay Grubitz temsilleri ile çerçevelenmiştir. Filmin bir sahnesinde, Stasi çalışanları kendi aralarında şakalaşmaktadır. Sosyalist Birlik partisi ile ilgili bir fıkra anlatan Stasi çalışanı, arkadaşlarının uyarısı ile hemen arkalarında yemek yemekte olan Yarbay Grubitz ve Yüzbaşı Wiesler'ı fark eder. Yarbay Grubitz, o çalışana adını ve hangi birimde çalıştı̆̆ını sorar. Yönetmenin yukarıda bahsettiği korku, Albay Grubitz karşısında titreyen Stasi çalışanının yüzünde açık bir şekilde görülmektedir. Başkalarının Hayatı filminde, Berlin Duvarı filmin hiçbir karesinde fiziksel olarak gözükmese de çeşitli sorgulama, gözetleme ve dinleme sahneleriyle (Şekil 7.) varlığını film boyunca hissettirir. Bu sahnelerle, Doğu Berlin'deki bu baskıcı otoriter yaşam dayanılmaz boyutlarda çerçevelenir. Bu yaşamın dayanılmazlığı, filmdeki iki karakterin intiharı ile de vurgulanır.

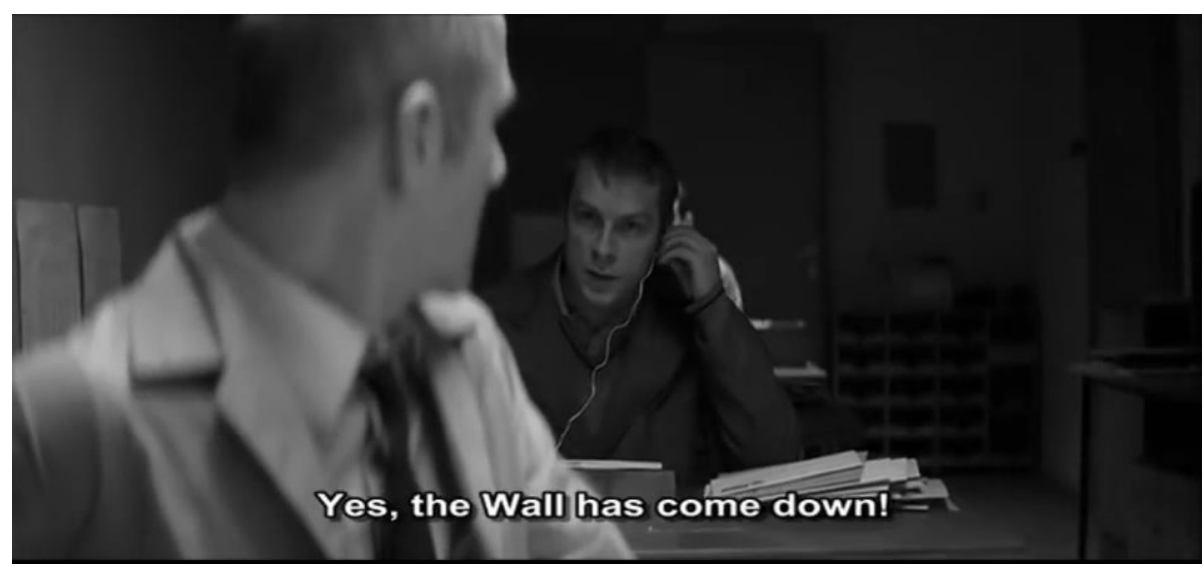

Şekil 8. Başkalarının Hayatı Filminde Berlin Duvarı'nın Yıkılışı (Kaynak: Quirin Berg (Yapımcı) ve Florian Henckel von Donnersmarck (Yönetmen). (2001). Das Leben der Anderen [Sinema Filmi], Almanya: Wiedemann \& Berg Filmproduktion.)

Duvarın varlığının fiziksel olarak filmde yer almayışı gibi, duvarın yıkılması da filmde görsel olarak yer almaz. Şekil 8'de gösterilen çekimle hem seyirci hem de filmin baş karakteri duvarın yıkılışını radyo haberinden öğrenir. Duvarın varlığı gibi, yıkılışı da filmde bir "dinleme" eylemiyle gösterilir. Filmde kullanılan sorgulama, dinleme ve kayıt cihazları "Stasi" tarafından kullanılmış gerçek aksesuarlardır ve çekimler için müzelerden ve koleksiyonculardan alınmıştır. Şahsen iki yılını bir Stasi hapishanesinde geçirmiş olan 
filmin aksesuarcısı, filmin son sahnesinde görülen ve saatte altı yüz mektubu buhar yöntemiyle açabilen cihazın tamamen orijinalinin kullanılması için ısrar etmiştir. Başkalarımın Hayatı filmi, yönetmenin 2006 yılında başvurduğu Berlin Film Festivali'nde, festival yönetmeni Dieter Kosslick ve ön eleme jürisi tarafından reddedilmiş, (Smith, 2007) ancak 2007 yılındaki Akademi Ödüllerinde "Yabancı Dilde En İyi Film" dalında Oscar ödülü kazanmıştır. Bununla birlikte çeşitli uluslararası film festivallerinde çeşitli dallarda toplam 66 ödül kazanmış, 22 dalda da aday gösterilmiştir.

\section{Bulgular ve Sonuç}

Berlin şehrinin ve Alman toplumunun bir bölümünün, şehrin ortasından örülen bir duvarla izole edilmesi ve sürekli bir baskı ve korku ortamı içinde bulunan karakterlerin bu izole edilmiş dünyadan kaçma arzularının yer aldığ1 dört filmin öykü evreninin kaçış, baskı, korku ve Berlin Duvarı́nın insanlar üzerinde yarattı̆̆ bunalım çerçeveleriyle yansıtıldığı tespit edilmiştir. Berlin duvarı ve bölünmüş Almanya'nın dolaylı ya da direkt olarak hikayelerinin temelini oluşturduğu bu dört film, 1963 ve 1989 yılları arasında Berlin şehrinin ortasında inşa edilen duvarla ikiye bölünen bir şehirde yaşanılanları beyazperdeye yansıtmıştır. Bu filmlerde çizilen çerçevelerin en belirgin ortak noktası, yarattıkları klostrofobi duygusudur: Filmlerde etrafına çevrili olan bir duvarla, Batı dünyasına tamamen kapatılmış Doğu Berlin ve vatandaşlarının ülke dışına çıkışlarını yasaklamış olan Doğu Almanya Devleti'nde yaşananlar gözler önüne serilmiştir. Ele aldığımız dört filmde de Sovyet yönetimindeki Doğu Almanya, kaçmak için ölümü göze almaya değecek derecede yaşanılmaz ve boğucu bir yer olarak çerçevelenmiştir. Totaliter rejimin baskıcı uygulamalarından ve kötü hayat şartlarından kurtulmak isteyen Doğu Almanya vatandaşları, Batı Berlin'e kaçma çabası içine girerek bunun için hayatlarını kaybetme riskini bile göze almışlardır. Bu çalışmada ele alınan Başkalarının Hayatı ve Berlin Üzerinde Gökyüzü filmlerinin dışındaki diğer iki filmde insanların tehlikeli bir şekilde Batı Berlin'e kaçışını gösteren sahneler vardır. Başkalarının Hayatı ve Berlin Üzerinde Gökyüzü filmlerindeki kaçma isteği ise intihar eylemiyle gerçekleştirilir. Tünel ve Berlin'de Cenaze filmleri "kaçış" olgusunun en çok vurgulandığı filmler olarak karşımıza çıkmaktadır. Bu kaçışlar sırasında pek çok insan dramatik bir şekilde yaşamını yitirmiştir. Batı Berlin'e kaçmaya çalışırken sınır polisi tarafından kalçasından vurulup 
sınırın ortasına düşen Peter Fechter'in, hiç kimsenin müdahale edememesi nedeniyle kan kaybından yaşamını yitirmesi Tünel filminde çarpıcı bir şekilde yeniden canlandırılırken, Berlin'de Cenaze'de ise insanların sınırı geçtiği ya da geçmeye teşebbüs ettiği çok sayıda sahneye yer verilmiştir. Bu filmlerin çoğunda çerçevelenen diğer önemli bir unsur ise Doğu Alman gizli polis teşkilatı "Stasi"nin varlı̆ğ ve insanlar üzerindeki yıldırıcı baskıları ve denetimleridir. Başkalarının Hayatı filminin hikayesinin temel çerçevesini, "Stasi” teşkilatı ve onun ülkenin aydın ve sanatçılarına olan olumsuz etkisi oluşturmaktadır. Bu film ayrıca, diğer filmler arasında Berlin Duvarı'nın yıkılmasından sonraki dönemi de hikayesine dahil eden tek filmdir. Tünel filmi yaşanmış gerçek olaylardan uyarlanmıştır. Diğer filmlerin senaryoları ise kurmaca olmalarına rağmen söz konusu tarihsel dönemi gerçeğe yakın bir biçimde çerçeveleyerek beyazperdeye yansıtmıştır. Örneğin Başkalarımın Hayatı filminin baş karakteri olan Yüzbaşı Wiesler' canlandıran Ulrich Mühe, Doğu Almanya döneminde tanınmış bir tiyatro oyuncusudur. Mühe, Berlin Duvarı'nın yıkılmasının ardından kendisi gibi oyuncu olan eski eşi Jenny Grollman'ın bir Stasi muhbiri olduğunun ortaya çıktığını iddia etmiştir. (Bergan, 2007) Bu filmler arasında bir tek Wim Wenders'in Berlin Üzerinde Gökyüzü filmi gerçek üstü ve fantastik öğeler barındırır. Ancak bu filmde de bölünmüş Berlin halkının günlük yaşamına hâkim olan ruh hali etkili bir şekilde yansıtılmıştır. Berlin Üzerinde Gökyüzü ve Berlin'de Cenaze filmleri, Berlin Duvarı'nın varl1ğını sürdürdüğü yıllarda gerçek duvarı çerçeveleme olanağına sahip olarak yapılmışlardır. 1987 yılı yapımı olan Berlin Üzerinde Gökyüzü'nün çekimlerinden iki yıl sonra Berlin Duvarı yıkılmıştır. Başkalarının Hayatı, Berlin Duvarı'nın yıkılmasından tam 17 yıl sonra, Tünel ise 12 yıl sonra çekilmiştir. Örnekleme dahil edilen dört filmde de, Berlin Duvarı'nın iki farklı şehre böldüğü Berlin ve orada yaşayan insanlar üzerinde kurulmuş olan baskının, yaşananlara paralel ve gerçekçi bir biçimde çerçevelediği gözlenmiştir. 


\title{
EXTENDED ABSTRACT
}

\section{Berlin Wall: The Symbol of the Cold War and Its Reflections in Cinema}

\author{
Cem Yildirim \\ İstanbul Ayvansaray University
}

After the end of the Second World War, Germany was the most concrete place in the cold war between the United States and the Soviet Union, which emerged as two superpowers aimed at establishing an ideological domination on the earth. As a result of this cold war policy, Germany split into two in 1949: West German Federal Republic (West Germany) and East German Democratic Republic (East Germany). Although the city of Berlin remained within the borders of East Germany, it was divided into two by an agreement between the Western bloc countries and the Soviets. On August 13, 1961, the East Berlin administration began building a wall around East Berlin that closed all the passages of the West section where its citizens had a more free and prosperous life on August 13, 1961. This wall was under the constant supervision of armed East German soldiers who were authorized to shoot anyone trying to escape to West Berlin. The Eastern Bloc claimed that this wall was built as a protection against fascist elements who wanted to break the will of the people who wanted to establish a socialist state in East Germany. However, the Berlin Wall originally served to prevent the massive immigration and asylum of people living in East Germany in the post-World War II period. The Berlin Wall was officially called the "Anti-Fascist Protection Trench" (Antifaschistischer Schutzwall) by the German Democratic Republic. This naming implied that West Germany outside the wall contained "Nazi elements". The West Berlin Governorate described the Berlin Wall as the "wall of shame".

The Berlin Wall has existed for 28 years until it was demolished on November 9, 1989. During this period, hundreds of people lost their lives trying to escape to the West Berlin by crossing the Berlin wall. The Berlin Wall as a social and political phenomenon and the division of Germany represented by this wall are also reflected in film narratives. A large number of motion pictures were made, which put the Berlin Wall at the center 
of their stories. The aim of this study is to reveal how the Berlin Wall as a political phenomenon and what happened in East and West Berlin during the cold war period between 1961 and 1989 were reflected in these films. Within the scope of the study, firstly, the historical background of the Berlin Wall and the social and political events experienced during the cold war period is discussed, and then the movies selected as samples are analyzed using the "frame analysis" method.Framing is the part that is included in the frame, the point that the person / director determines the frame as the center of attention and wants us to see. With the established framework, the subject is placed in a new context and the existing reality is reshaped. It is possible to express that the frames turn into tools that make sense on the event or subject presented by being reconstructed. This work is limited to four feature-length feature films that took the Berlin Wall and the division of Germany between 1961 and 1989 at the center of their stories and were shot in Berlin. These films are: Der Tunnel (2001) directed by Roland Suso Richter, Der Himmel Über Berlin (1987) directed by Wim Wenders, Life of Others (2006) directed by Florian Henckel Donnersmarck and Funeral in Berlin (1966) directed by Guy Hamilton.

It has been determined that, the story universe of these four films is framed by a wall built in the middle of the city, and the characters' desire to escape from this isolated world which is an environment of constant pressure, fear and oppression. The most prominent common point of the frames drawn in these films is the feeling of claustrophobia they create: A wall surrounded in the films reveals what happened in East Berlin, which was completely closed to the Western world, and the East Germany State, which prohibited its citizens from leaving the country. In all four films we consider, Soviet-led East Germany has been framed as an uninhabitable and suffocating place worth the risk of death to escape. East Germans who want to get rid of the oppressive practices and bad living conditions of the totalitarian regime, attempt to escape to West Berlin and risk losing their lives for this. Der Tunnel (2001) and Funeral in Berlin (1966) contain scenes showing people escaping dangerously to West Berlin.The desire to escape from East Berlin, in Lives of Others (2006) and Der Himmel Über Berlin (1987) is accomplished by suicide. Der Tunnel (2001) and Funeral in Berlin (1966) in Berlin are the films in which the phenomenon of "escape" is emphasized the most. Many people died dramatically during these escapes. 
The death of Peter Fechter, who was shot in the middle of the border by the border police while trying to flee to West Berlin, strikingly recreated in Der Tunnel (2001). In Funeral in Berlin (1966) contain many scenes in which people cross the border or attempt to cross. Another important element framed in many of these films is the presence of the "Stasi", the East German secret police, and their daunting pressure and control over people. The main frame of the story of Lives of Others (2006) is the "Stasi" organization and its negative impact on the intellectuals and artists of the country. Among these films, only Wim Wenders' Der Himmel Über Berlin (1987) contains surreal and fantastic elements. However, this film also effectively reflects the mood of the divided Berlin people in their daily life. Der Himmel Über Berlin (1987) and Funeral in Berlin (1966) were made with the opportunity to frame the real wall during the years of the Berlin Wall. Two years after the shooting of the Der Himmel Über Berlin (1987) the Berlin Wall fell. In all four films included in the study, it is observed that the Berlin Wall divides the city of Berlin into two different cities and frames the pressure it exerts on the people living there in a realistic and parallel to what happened.

\section{Kaynakça / References}

Akmeşe, E. (2020). Ötekileştirmenin diyalektiği bağlamında bireyin varoluşsal bunalımı üzerine bir analiz: Çoğunluk 2010 Middle Black Sea Journal of Communication Studies, 5(1), 57-64.

Akmeşe, Z. (2020) Televizyon ana haber bültenlerinde çerçeveleme: Türk telekom reklam filmi örneği, Middle Black Sea Journal of Communication Studies, 5(1) 37-49.

Akmeşe, Z. ve Arda, Ö. (2020). Ken Loach sinemasında 'Özgürlük Teması' ve 'Özgürlük Rüzgârı' filminin çerçeveleme çözümlemesi. OPUS Uluslararası Toplum Araştırmalar Dergisi, 15 (23), 2108-2131.

Berg, Q. (Yapıma) ve Florian Henckel von Donnersmarck (Yönetmen). (2001). Das Leben der Anderen [Sinema Filmi].Almanya:Wiedemann \& Berg Filmproduktion.

Bergan, R. (2007, Temmuz 28). Volksbühne Ulrich Mühe. The Guardian. 21 Mart 2020 tarihinde https://www.theguardian.com/news/2007/jul/28/guardianobituaries.obituaries/ adresinden erişildi.

Brockmann, S. (2010). A critical history of German film. New York: Camden House, 2010. 
Cerrahoğlu, N. (2013, Ağustos 4). Sırdaş polis ve başkalarının hayatı. Cumhuriyet. 11 Kasim 2019 tarihinde http://www.cumhuriyet.com.tr/koseyazisi/437764/_Sirdas Polis ve Baskalarinin Hayati.html/ adresinden erişildi.

Construction of The Wall in Agust 1961. (t.y.). 4 Kasim 2019 tarihinde http://www.berliner-mauer-gedenkstaette.de/en/mauerbau-46.html/ adresinden erişildi.

Corliss, R. (2011, Ağustos 9). The Tunnel. Time. 17 Kasım 2019 tarihinde https://entertainment.time.com/2011/08/11/top-10-berlin-wall-movies/slide/the-tunnel2001/ adresinden erişildi.

Crowther, B. (1966, Aralık 23). Screen: 'Funeral in Berlin' Begins Run:Michael Caine Returns as Harry Palmer Soft-Sell Secret Agent Betrayed by Script. The New York Times. 17 Kasim 2019 tarihinde https://www.nytimes.com/1966/12/23/archives/screen-funeral-in-berlin-begins-runmichaelcaine-returns-as-harry.html/ adresinden erişildi.

Dauman, A. (Yapımc1) ve Wim Wenders (Yönetmen). (1987). Der Himmel über Berlin [Sinema Filmi], Batı Almanya-Fransa: Road Movies Filmproduktion.

Delacroix, H.M (2016). Willy Brandt: Life of a statesman .New York: I.B. Touris

Entman, R. M. (1991). Framing U.S. coverage of international news: Contrasts in Narratives of the KAL and Iran Air ve Incidents. Journal of Communication 41, 6-27.

Fatalities at The Berlin Wall. (t.y.). 6 Kasım 2019 tarihinde $\quad \underline{\text { http://www.berliner- }}$ mauer-gedenkstaette.de/en/todesopfer-240.html/ adresinden erişildi.

Friedman, M.J (Der). (2009). The Berlin Wall- 20 Years Later. U.S Department of StateBureu of International Information Program. 4 Kasim 2019 tarihinde https://photos.state.gov/libraries/amgov/30145/publications-english/theberlin-wall.pdf/ adresinden erişildi.

Gearson, J. ve Schake, K. (Der). (2002). The Berlin Wall crisis: Perspectives on cold war alliances. New York: Palgrave Macmillan.

Harrison, H. (2011). The Berlin Wall after fifty years: Introduction. German Politics $\mathcal{E}$ Society, 29(2(99)), 1-7. 28 Nisan 2020 tarihinde http://www.jstor.org/stable/23744556 adresinden erişildi.

Hofmann, N. (Yapımc1) ve Roland Suso Richter (Yönetmen). (2001) Der Tunnel [ Sinema Filmi]. Almanya: Sat.1 teamWorx Television \& Film.

Kasher, C. D. (Yapımc1) ve Guy Hamilton (Yönetmen). (1966). Funeral in Berlin [Sinema Filmi]. Birleşik Krallık: Jovera Pictures AG/SA.

Kern, L. (2005, Nisan 29). In a divided Berlin, Digging Underground For Freedom. The New York Times. 17 Kasim 2019 tarihinde http:/www.nytimes.com/2005/04/29/movies/29tunn.html? r=1\&/ adresinden erişildi. 
Major, P. (2010). Behind the Berlin Wall: East Germany and the frontiers of power. Oxford: Oxford University Press.

Memorial For Peter Fechter. (t.y.). 7 Kasım 2019 tarihinde $\underline{\text { https://www.ber- }}$ lin.de/mauer/en/sites/memorials/memorial-for-peter-fechter479163.en.php/ adresinden erişildi.

Mering, S. ve Wyman T. (2013). Introduction. S.Mering ve T. Wyman (Der.), Rightwing radicalism today: perspectives from Europe and the US içinde (s. 1-7). New York, NY: Routledge.

Öztürk, M. (2008). Sinematografik kentler: Mekanlar, hatıralar, arzular. Agora Kitaplı̆ğ: İstanbul.

Ramos, S. (2007, Temmuz 23) Why dictaors fears artists. 11 Kasim 2019 tarihinde http://www.firstthings.com/onthesquare/2007/07/why-dictators-fear-artists/ adresinden erişildi.

Roberts, J. M. (2003). Yirminci Yüzyıl tarihi. (S. Gül, Çev.). Ankara: Dost Kitabevi Yayınları.

Rottman, G. L. (2008) The Berlin Wall and The Intra-German border 1961- 89. Oxford: Osprey Publishing.

Smith, D.G (2007, Şubat 2). Cinephile paradise: Filmlovers flock to Berlin film festival. Der Spiegel. 15 Kasım 2019 tarihinde http://www.spiegel.de/international/cinephile-paradise-filmlovers-flock-to-berlin-film-festival-a-464651.html/ adresinden erişildi.

Taylor, F. (2006) The Berlin Wall- A World divided. New York: Harper Collins Publishers Inc.

The Fall of The Berlin Wall. (t.y.). 7 Kasım 2019 tarihinde http://www.berliner-mauergedenkstaette.de/en/fall-of-the-berlin-wall-291.html/ adresinden erişildi.

The Life of Others-Director's Statament. (t.y.). 12 Kasım 2019 tarihinde https://www.sonyclassics.com/thelivesofothers/externalLoads/TheLivesofOthers.pdf/ adresinden erişildi.

Wenders, W. ve Hofmann, M. (1991) The logic of images- Essays and conversations. Londra: Faber and Faber.

\section{Kaynakça Bilgisi / Citation Information}

Yıldırım, C. (2020). Soğuk savaşın simgesi Berlin Duvarı ve sinemadaki yansımaları. OPUS-Uluslararası Toplum Araştırmaları Dergisi, 16(32), 5176-5203. DOI: 10.26466/opus.797448 